NOTE

\title{
Immersion periods in four neotropical turtles
}

\author{
Bernal Morera-Brenes ${ }^{1} \&$ Julián Monge-Nájera ${ }^{2}$ \\ ${ }^{1}$ Laboratorio de Genética Evolutiva, Escuela de Ciencias Biológicas, Universidad Nacional, Heredia, Costa Rica; bernal.morera@gmail.com \\ ${ }^{2}$ Vicerrectoría de Investigación, Universidad Estatal a Distancia, 2060 San José, Costa Rica; julian.monge@ucr.ac.cr, julianmonge@gmail.com
}

Recibido 30-VII-2010 Corregido 20-VIII-2010 Aceptado 31-VIII-2010

Semi-aquatic turtles often dive to escape from terrestrial predators, but to our knowledge, the time that Costa Rican species can stay under water is unknown. To obtain preliminary measurements of this ecologically significant parameter, we tested several individuals in an aquarium with water at $25^{\circ} \mathrm{C}$ in Sabanilla, San José, Costa Rica. We placed the turtles in the water and moved a hand on the surface whenever they attempted to swim upwards, but otherwise allowed them to resurface. They were all adult females except for Kinosternon scorpioides (3 males, 1 female).

The times they stayed under water were: $K$. scorpioides 60-3656s (15 repetitions); Kinosternon leucostomum 82$84 \mathrm{~s}$ (6 repetitions); Rhinoclemmys pulcherrima 413-435s ( 2 repetitions) and $R$. funerea 525 seconds (one test).
The maximum time was of about one hour, recorded for a female K. scorpioides. Standora et al. (1984) found that in nature, submersion times for the marine Dermochelyx coriacea averaged 480 seconds, similar to the times we recorded for Rhinoclemmys spp.

We thank M. Sassa for advice.

\section{REFERENCE}

Standora, E.A., J.R. Spotila, J.A. Keinath \& C.R. Shoop. 1984. Body temperatures, diving cycles, and movement of a subadult leatherback turtle, Dermochelys coriacea. Herpetologica 40:169-176.

Article edited by Vanessa Nielsen-Muñoz 